\title{
Reklam, Kültür ve İletişim
}

Doç. Dr. Pervin Nedim Bal ${ }^{1 *}$

Dr. Öğr. Üyesi Mualla Murat Nuhoğlu²

Büşra Erkan ${ }^{3}$

Şeyma Doğan ${ }^{4}$

Rumman Emine Öner 5

Gelis tarihi: 21.12.2019

Kabul tarihi: 14.02.2020

\section{Atıf bilgisi:}

IBAD Sosyal Bilimler Dergisi

Sayı: 7

Sayfa: $167-182$

Yıl: 2020 Dönem: Yaz

This article was checked by Turnitin. Similarity Index 20\%

Bu makalede araştırma ve yayın etiğine uyulmuştur.

\footnotetext{
${ }^{1}$ Beykent Üniversitesi, Türkiye, pervinbal@beykent.edu.tr

ORCID ID: 0000-0002-3090-6634

2 Türkiye, muallamurat@yahoo.com ORCID ID: 0000-0002-8872-8973

${ }^{3}$ Türkiye, erkanbusraa@gmail.com ORCID ID: 0000-0002-8109-7494

${ }^{4}$ Türkiye, seymadogann@hotmail.com ORCID ID: 0000-0002-3456-6489

${ }^{5}$ Türkiye,

rummanoner1997@gmail.com

ORCID ID: 0000-0001-6779-5539
}

\section{*Sorumlu yazar}

Özet

Reklam, kapitalizme hizmet eden en önemli sektörlerden biridir. Tüketicinin ilk etapta bilinçli ya da bilinçsiz kullandığı bir araç olarak reklam, teknolojinin getirdiği imtiyazla ekonominin yönünü tespit eder. İnsanlığın, etkisinden kurtulamadığı reklam sektörü iletișimin de bir aracıdır. Tüketiciyi ihtiyacı olsun olmasın her şartta satın almaya ikna edici gerekçe ve durumları yaratma beceri ve toplamı olarak özetlenebilen reklam olgusu, günün her saniyesinde beş duyumuzla maruz kaldığımız, psikolojik olarak etkilenmenin kaçınılmaz olduğu, yüzyılın en çok gelir sağlayan para kaynaklarından biri olarak değerlendirilmektedir. Bu kadar önemli bir sektör, kendi alanı içindeki kuram ve ilkeler kadar ürünün sunulduğu hedef kitlenin de kültürünü ve sosyal yaşantısını iyi bilmek ve irdelemek zorundadır. Bütün ülkelere ürün satan bir markanın her ülkeye göre hazırladığı reklam birbirinden farklıdır ve hedef kitlesinin kültürünü taşır. Reklam, aynı zamanda bir iletişim aracıdır. Duygu ve düşüncelerin tezahürünü taşır. Duygu ve düşüncelerin nesiller arasındaki farkı da önemlidir. Nesillerin kültürel değerleri dikkate alınarak hazırlanan reklamların hedef kitlelerinin ürüne yaklaşımı o reklamın başarısını gösterir. Bütün bunlar bilinirken arka planda bilinmeyen daha farklı değerler de vardır. Bir banka reklamında ürün, genç bir kızla bir delikanlı arasındaki sevgili ilișkisi içerisinde Transaksiyonel Analiz kuramı ile işlenerek dikkat çekecek bir şekilde sunulmuş ve böylelikle toplumun değer yargıları kullanılmıştır. $\mathrm{Bu}$ çalışmada Erich Berne'nin Transaksiyonel Analiz kuramı kullanılarak bir banka reklam filminin yorumlaması yapılmış ve kültürel değerlerin reklam sektörüne etkisi tespit edilmeye çalışılmıştır.

Anahtar kelimeler: Reklam, Kültür, Eğitim, İletişim. 


\title{
Advertising, Culture and Communication
}

\author{
Assoc. Prof. Dr. Pervin Nedim Bal ${ }^{1 *}$ \\ Assist. Prof. Dr. Mualla Murat Nuhoğlu \\ Büşra Erkan ${ }^{3}$ \\ Şeyma Doğan 4 \\ Rumman Emine Öner ${ }^{5}$
}

First received: 21.12 .2019

Accepted: 14.02.2020

\section{Citation:}

IBAD Journal of Social Sciences

Issue: 7

Pages: 167-182

Year: 2020

Session: Summer

This article was checked by Turnitin. Similarity Index 20\%

\footnotetext{
${ }^{1}$ Beykent Üniversitesi, Türkiye, pervinbal@beykent.edu.tr ORCID ID: 0000-0002-3090-6634

2 Türkiye, muallamurat@yahoo.com ORCID ID: 0000-0002-8872-8973

${ }^{3}$ Türkiye, erkanbusraa@gmail.com ORCID ID: 0000-0002-8109-7494

4 Türkiye, seymadogann@hotmail.com ORCID ID: 0000-0002-3456-6489

${ }^{5}$ Türkiye, rummanoner1997@gmail.com ORCID ID: 0000-0001-6779-5539
}

\footnotetext{
* Corresponding Author
}

\begin{abstract}
Advertising is one of the most important sector serving capitalism. Advertising as a tool, which is used by the consumer, consciously or unconsciously in the first place determines the direction of the economy with the privilege brought by technology. The advertising sector, which humanity cannot get rid of its influence, is also a means of communication. The advertising phenomenon, which can be summarized as the sum of the skills and ordinances to create convincing reasons and situations to buy in every condition whether the consumer needs it or not, is considered to be one of the most income-generating sources of money in this century that we are exposed to by our five senses every second of the day, and where psychologically influenced is inevitable. Such an important sector has to know and examine the culture and social life of its target audience to which the product will be presented as well as the theories and principles within its field. The advertising prepared by a brand that sells products to all countries is different from each other according to each country and carries the culture of its target audience. Advertising is also a means of communication. It conveys the manifestation of emotions and thoughts. The difference between emotions and thoughts across generations is also important. The approach of the target audience to the product shows the success of that advertising which is prepared by considering the cultural values of the generations. While all this is known, there are also different values that are unknown in the background. In a bank advertisement, the product is presented in a remarkable way by using the theory of transactional analysis within the beloved relationship between a young girl and a young man, and thus the value judgments of the society are used. In this study, a bank advertising film is interpreted by using transactional analysis theory of Eric Berne and it is attempted to determine the effect of cultural values on the advertising sector.
\end{abstract}

Keywords: Advertising, Culture, Education, Communication. 


\section{GİRIŞ}

Dil, bütün alan yazınlarının anlama becerilerinin temelidir. İnsan ve insanlığın gelişimi dil sayesinde olur. Dil eğitimi belli bir yaştan sonra sahip olunan mesleklerin başarısını sağlayan en temel özelliktir. İnsan için, dilin seviyesi yaşamının da seviyesini belirler. Dil bilgisi eğitimi MEB'de 1. sınıftan 12. sınıfa kadar yer alırken, YÖK akademide ön lisans ve lisanslarda da 1. sinıflarda bu alan yazınına müfredatta yer vermiştir.

Dil bilgisi üzerine yapılan çalışmalarda dil bilgisinin çok yönlü ele alınabileceği görünmüştür. Çalışma boyutlarından birisi; "Klâsik veya geleneksel dil bilgisi denilen' Biçimbilimsel Dil Bilgisi, Üretimci ve Dönüşümcü Dil Bilgisi, Kavramsal-İş̧levsel Dil Bilgisi, Söyleyiş Dil Bilgisi, Metinsel Dil Bilgisi' gibi. Okullarda hangi bilgilerin verilmesi gerektiği tartışmaları sonucu' Eğitim Dil Bilgisi ya da Okul Dil Bilgisi 'ortaya çıkmış, bunların özellikleri dönüşümcü ve paylaşımcı olarak nitelendirilmiştir. Son yıllarda 'Metin Dil Dilgisi ve Yararlı Dil Bilgisi' gündeme gelmiştir” (Güneş, 2013) şeklinde sıralanabilir, ayrıca dil bilgisinde incelenen konular; bir dili oluşturan ses, kelime, cümle ve metin gibi ögeler yapı, tür, görev, işleyiş ve anlam yönüyle incelenmekte ve çeşitli kurallar ortaya konulmaktadır (Güneş, 2013).

Okullarda verilen dil eğitiminin temel amacı, öğrencilerin bulundukları sınıf seviyesinin kazanımlarına uygun olarak okuma, dinleme, konuşma ve yazma becerilerini kazandırmak ve etkili bir şekilde kullanmalarını sağlamaktır (Göçer, 2015).

Dil bilgisi eğitimi, davranışçı, yapılandırmacı ve bilişsel olmak üzere en çok kullanılan bu yöntem ve tekniklerle verilmiştir. Dil bilgisi öğretiminde bunların dışında da ortaya konmuş pek çok yöntem ve teknik vardır. 2005'ten sonra MEB'de yapılandırmacı yaklaşım genel olarak kabul gördüğü için dil bilgisi eğitiminde de yapılandırmacı yaklaşıma özen gösterilmektedir. Yapılandırmacı yaklaşımda en önemli nokta bilgiyi ezberletecek şekilde aktarmak yerine sezdirerek öğretmek söz konusudur.

Sezdirme Yöntemi: Yapılandırıcı yaklaşım ve yeni dil bilgisiyle birlikte uygulanan sezdirme yöntemi, dilin soyut kurallarını ezberleme değil, öğrencinin dil ve zihinsel becerileri geliştirmeyi amaçlamaktadır (Güneş, 2013).

Reklam metinleri, Türkçe eğitim programlarında yer alan pek çok konuyu karş1layabilecek işlevdedir. Çift eklemli bir dil olan Türkçe, metin bilgisiyle dil bilgisi işlerliğini de karşılayan reklamlar aynı zamanda Türkçe temalarda yer alan kültürün de aktarıcısıdır. Psikolojik, sosyolojik, ekonomik, felsefi, sağlı gibi pek çok alanların temelinden faydalanan reklam sektörü gibi Türkçe eğitiminde de aynı alanlara yer verilir. Türkçe eğitimi konularından olan mitoloji reklam sektörününde sıklıkla başvurduğu alanlardan biridir. Örnekler bölümünde Türkçe eğitimindeki beklentileri karş1layabilecek reklam ürünleri tespit edilmeye çalışılmıştır.

\section{Reklam}

TDK'nın hazırladı̆̆ 1 Türkçe Sözlükte; "Reklam” “(Fr. Reclame) bir şeyi halka tanıtmak, beğendirmek ve böylelikle sürümünü sağlamak için denenen her türlü yol" olarak tanımlanmaktadır (TDK sözlüğü, 1998).

Reklamın idealize edilmiş söylem ve hayal evreninde yer alan tüm unsurlar, var olan toplumsal oluşumun kodları kullanılarak tasarlanan üst gerçeklik imgeleridirler (Mengü, 2006).

Reklam, iletişim açısından ele alındığında bir bilgi verme ve ikna etme aracı olarak düşünülmekte, geniş halk kitlelerine bir ürün ya da hizmetin duyurulması anlamında kullanılmaktadır (Aktuğlu, 2006).

Judith Williamson, "Reklamın İşlevi" hakkında şunları söylemektedir: "Reklamın açık işlevi şeyleri bize satmaktır. Reklamlar, sadece satmaya çalıştıkları ürünlerin doğasında var olan nitelik ve özellikleri değil, bu malların bizim için ifade ettikleri değişim değerlerini anlatır. Reklam 'Şeyler'in bu ifadelerini, insan ifadeleri olarak bize tercüme eder; onlara insani olarak bir simgesel değişim-değeri verilir. Reklamlar, daha çok nesnelerin dilini insanların diline dönüştürebilen ve tersini yapabilen bir yapı oluşturur" (Aktaran: Yılmaz, 2004). 
Reklamın amacı, ürün satmaktır. Bu amaca ulaşmada kullanılan yol ise iletişimin temelini oluşturan dildir. Dil eğitimi bireyin ve toplumun ekonomik sorunlarını düzenleyici ve çözümleyici olarak önem verilmelidir. Birey, çocukluktan başlayarak doğa, sosyal hayat ve kendi varlığıyla ilgili bilgiler ve düşünce biçimleri edinmeye başlar (Kalan, 2010).

Televizyon reklâmlarında görsel öğeler sunulurken olaylar sıkıştırılır ve son derece ilgi çekici biçimde verilmeye çalış1lır. İlgi çekmek, ilgiyi toplamak kişileri ikna edebilmek için önemli bir koşuldur (Kütük, 2012). Kelime haznesi kadar görsel okumadaki sembol, imge ve objelerin anlamları da ifade ve iletişim için önemlidir. Çağımızda insan hayatını etkileyen reklamların, bireyin düşünme becerisi ile hayatını iyi yönetmesi algı ve kültüre bağlıdır.

\section{Reklam Psikolojisi}

Reklam psikolojisi; ileri lisans, yüksek lisans öğrencileri, sosyal psikoloji, pazarlama, iletişim alanındaki araştırmacılar ve öğretim üyeleri için eşsiz ve paha biçilmez bir kaynaktır. Aynı zamanda reklam, halk sağlığı, kamu hizmetleri ve siyasi iletişimde çalışan profesyoneller için değerli bir rehberdir (Fennis \& Stroebe, 2015). Reklam psikolojisini açıklamak için psikoloji ve reklam tanımlarından yola çıkarak şunlar söylenilebilir: Psikoloji insan doğasını, ruhunu ve insanların neden yaptıkları gibi davrandıklarını araştırır. Reklam ise, belirli satın alma kararlarını vermek için insan davranışını etkileme sanatını araştırır. Öyle ise bu iki alanın birleşmesi sürpriz değildir. İster geleneksel isterse dijital taktikler kullanılmakta olsun, reklamların arkasındaki psikolojiyi anlamak önemlidir. Gazete, dergi, radyo, doğrudan posta ve pano Geleneksel Reklamlar olarak bilinirken; sosyal medya, Google reklamlar1, arama motoru, görüntüleme, gelen kutusu, sponsorlu listeler ise Dijital Reklamlar olarak adlandırılmaktadır. İster bir Google reklamı yayınlanmak istensin, isterse bir reklam panosu oluşturulmak istensin, her iki reklam türü için de düşünme veya duygu yaklaşımlarından birinin seçilmesi gerekecektir. Reklamların düşünme yaklaşımları, tüketicilerin ürünü özelliklerine veya bir problemi çözmeye dayalı olarak satın almak için mantık ve sebep kullanmalarına izin verir. Apple'ın iPhone XS ve iPhone XR'nin yeni özellik lansmanını tanıtan reklam, düşünce yaklaşımı kullanılan reklamlara bir örnektir. Bu reklamların, ürünlerinin belirli özelliklerini ve faydalarını pürüzsüz olarak vurguladıkları açıktır. Duygu yaklaşımları ise tüketici davranışlarını yakalamak için duygu kullanır. Reklamda, eğlence, fantezi veya korku olsun ya da olmasın duygu yaklaşımı, tüketicileri duygu kullanarak ikna eder. Apple, insanları hediye paylaşmaya ikna etmek için iyi-duygu yaklaşımını kullanmaktadır. Reklam için duygu yaklaşımı kullanılmaya karar verildiyse, ürününüze, hedef kitlenize ve markanıza en iyi hitap eden duyguyu seçmek önemlidir. Reklamcılıkta kullanılan 4 temel duygu vardır; mizah, korku, heyecan, üzüntü. Mizah, hatırlanabilirliği artırır. Bir reklamda korku kullanmak zor olabilir ancak, doğru yapılırsa çok etkili olabilir. Eğer bir özellik lansmanı ya da kitlenizle paylaşmak için heyecan verici bir şey varsa heyecan kullanarak reklam mükemmel olabilir. Heyecan zihninizin ve vücudunuzun tepki göstermesine neden olur. $\mathrm{Bu}$ da insanların harekete geçme ve satın alma kararı verme olasılığını daha yüksek hale getirebilir. İnsanları üzmek dikkatlerini çekmek için harika bir yoldur. Her duygu tüketicileri farklı bir şekilde ikna eder, bu nedenle seçilen duygunun ürün ve marka için en iyi eşleşme olduğundan emin olunmalıdır. Böylelikle reklam hedefine doğru, yani tüketiciyi satın almaya doğru götürecektir (Oregan, 2019). Watson, Reklamın etkili olabilmesi için, sevgi, korku ve öfke olmak üzere doğuştan gelen üç duyguya hitap etmesi gerektiğine inanıyordu. Watson'ın " ... reklamları çok diş macunu sattırdı. Bunu sebebi, muhtemelen diş hijyeni yararları nedeniyle değil, daha beyaz dişlerin bir bireyin cinsel çekiciliğini artıracağı içindir" (Benjamin \& Baker 2004, s. 121). Watson ayrıca pazar araştırması yapmaya inanıyordu, bu da reklamcılığa objektif, bilimsel yaklaşımlar uyguladığı anlamına geliyordu. Örneğin Watson, "belirli tüketicileri hedeflemek için demografik veriler" kullanmıştır (Goodwin, 1999, s. 316). Watson, reklamda ünlü onaylarının kullanımını teşvik etmiştir (Goodwin, 1999, s. 242).

Yurtdışında, reklam ve ikna psikolojisi üzerine çok sayıda araştırma yapılımıştır. Bu araştırmalarda sıradan (vasıfsız) insanların, reklam ve ikna psikolojisi hakkında neye inandıkları, meslekten olmayan kişilerin inançlarının tüketici araştırmacılarının inançlarına ne kadar benzediği, insanların, televizyon reklamcılığının izleyiciyi nasıl etkilediği hakkındaki kavramların içeriği araştırılmıştır. Bulgular, sıradan insanların ve araştırmacıların ikna psikolojisi hakkındaki birçok temel inancı paylaştı̆̆ını 
göstermekte, ancak bu grupların ikna bilgisinde bazı farkl1lıklar olduğunu da belirtmektedir. Bulgular, kültürel halk bilgisinin varlığı ve bunun ikna üzerindeki etkisi hakkında ne ifade ettiğini göstermektedir (Friestad \& Wright, 1995).

Üç ayrı çalışmada, öz-izleme kişilikleri yüksek veya düşük olan 130 lisans öğrencisinin iki reklam stratejisine yönelik değerlendirme ve davranışsal tepkileri incelenmiştir. Bu stratejilerin birinde ürünün görüntüsüne hitap edilir, diğerinde ise ürünün kalitesiyle ilgili iddialarda bulunulur. Yüksek öz-izleme düzeyine sahip olan öğrenciler, görüntü odaklı reklamlara daha olumlu tepki vermişlerdi, görüntü yönelimli reklamı yapılan ürünler için daha fazla para ödemeye isteklilerdi ve eğer bir görüntü cazip pazarlandıysa, bu ürünü denemeye daha isteklilerdi. Buna karşılık, düşük öz-izleme düzeyine sahip öğrenciler, ürün kalitesine yönelik reklamlara daha olumlu tepki göstermiş, kaliteli bir oryantasyonla ilan edildiyse, ürünler için daha fazla ödeme yapmaya daha istekli oldukları görülmüştür ve kalite iddiasıyla ile pazarlanan bir ürünü denemek için daha istekli olmuşlardır (Snyder \& DeBono 1985).

\section{Reklam, Dil ve Kültür İlişkisi}

Reklam, bireyde uyandıracağı algının en kuvvetli anlamı ile verilecek en kısa ve öz mesaj ile amacına ulaşır. Piktogramlar reklamın amacına ulaşmasında en çok kullanılan tercihlerden biridir. Piktogramın kelime anlamı bir eşyayı, bir objeyi, bir yeri, bir işleyişi, bir kavramı resmetme yoluyla temsil eden semboldür. Piktografi ise, dillerin daha üstünde daha evrensel bir anlatım dilidir. 26 Eylül 2018 tarihinde yayınlanan "Migros Sana Geliyor, Migros Sanal Market- MIGGOS Reklamı" başlıklı reklam buna örnek gösterilebilir.

14 Ekim 2019 tarihinde yayınlanan "Sende Ne Yetenekler Varmış Sıla- OPPO Reklamı” başlıklı Oppo A9 telefon reklamı, gündelik hayattan edinilen tecrübenin simgesel olarak atasözlerine yansıması şeklinde reklamlarda karşımıza çıkar. Cihazın marifeti ile ortaya çıkan meziyet insanın bu meziyeti kullanma hünerine bağlıdır. Bireyin evrensel ufka ulaşması için liyakatinin donanım gerektirdiği reklama yansımış bir atasözünde görülebilir.

Bireyin içinde var olduğu toplum bireyin kimliğini kişiliğini ve düşünme becerilerini geliştirir. Birey bu yolda aileden ve okuldan edindiği bilgi ve beceriler kadar sosyal hayattan da edinimler kazanır. Günümüzde teknolojinin getirdiği imkânlar bireyin kimlik, kişilik ve düşünme becerilerini geliştirme açısından önemli bir etkendir. Teknoloji çağının geniş hedef kitlelere hızla ulaştırdığı reklamlar, bireyin günlük tercihlerinde kolaylıkla yaşama biçimini ş̧ekillendiren etkenlere hâkimdir. Birey üzerinde eğitim, bir süreç sonucunda etkili olurken; reklamlar, anlık ve vurgulu etkileriyle bireyi daha kolay yönlendirmektedir.

Mengü (2006), Popüler kültüre uygun olarak anlamlandırılmış meta göstergeleri, reklamlarda değerlerin ve ideolojilerin yeniden üretimini gerçekleştirdiği düşüncesiyle görsellerin kelimelerle kaynaşarak, kelimeleri nasıl yorumlayacağımızı belirlediğimizi söyler.

Reklamın sonunda, reklamı yapılan marka ve ürünün tüketiciye sunduğu değeri anlatan sloganlar, toplumsal bellekte edindikleri yer açısından incelemeye değer sayılabilir (Mengü, 2006).

Reklam metni simgeler, resimler, markalar ve bütün görsel öğelerle birlikte ses ve müzik öğelerini de içerir (Bakır \& Çelik, 2013).

Bir marka, tıpkı bir insanın kişiliği gibi soyut ve somut birtakım nitelikleri kapsamaktadır. Reklam, edebi metnin en kısa, destan, efsane gibi türler ise en uzun yapıtlardır.

Yani edebi türlerin en kısa şekilde olanına reklam, en uzun şekilde olanlarına ise efsane, destan veya roman denilebilir.

Reklamlardaki dil kullanımında özellikle popüler kültürün ürettiği sözcükler, kalıplaşmış sözcükler, argo sözcükler reklamın diğer öğelerini arka planda bırakmakta ve dil ön plana çıkmaktadır. Dolayısıyla her 3 kriterde de hızlı tüketim ürünlerine ait reklamlarda tamamen duygusal "eğitim şart, aç kapa aç kapa, alsak alsak bedavaya ne alsak, hizmette sınır yoktur" gibi dilsel kullanımlar bireylerce zaman ve mekan gözetilmeksizin her yerde ve her zaman tüketilmekte, yeniden üretilmekte ve ön plana çıktığı görülmektedir (Mengü, 2006). 
20 Eylül 2014 tarihinde yayınlanan “Canga'nın Annesi - Eti Canga Reklamları” başlıklı gençliğin genel problemi olan sorumluluk ve düzen yaşantısını iki nesil arasındaki fark ve anlayışla veren "Canga" reklamı psikolojik olarak da duygular arasındaki ilişkileri düzenleyen bir reklamdır.

Dış dünya ile ilişkiler dil sayesinde kurulmaktadır, bu dış dünyanın insan tarafından anlaşılabilmesi için; nesnelerin anlamlandırılabilir kavramlara dönüştürülerek, insan beynine yerleştirilmesi ve bunların dilsel sembollerle ifade edilebilecek düzeye gelinmesi daha sonra da, dilde yeniden kurulup yaşam alanlarına aktarılması gerekmektedir.

18 Şubat 2019 tarihinde yayınlanan “Kirlenmek Güzeldir - OMO Reklamı” başlıklı hijyen takıntılığına karşı, çocuğun hak ve özgürlüğü için "Kirlenmek Güzeldir”" sloganı ile çalışma yapan OMO reklamı bireyin ve toplumun yaşantısını yeniden düzenlemektedir.

Dil bir soyutlamadır ve soyutlama yapılırken de asıl varlığa atfedilen kavram ve anlamın getirdiği sınırlılıklardan dolayı bir yabancılaştırıcılık taşımaktadır; çünkü dış dünyayı tanımlamak ve anlamlandırmak için onun dışında olmak veya ona dışarıdan bakabilmek gerekmektedir (Demir, 2005).

2 Mayıs 2019 tarihinde yayınlanan "Elidor Yeni Reklam-Elidor Doğanın Enerjisi "güç doğamızda var" başlıklı Elidor Şampuan reklamı doğayla metafor yapılan Elidor reklamında genellikle hanımların saçları kullanılarak çeşit çeşit doğa unsurlarının güç özellikleri ortaya çıkartılarak ürünün tüketimine özendirilmiştir.

Edebi metinlerle reklamlar arasındaki önemli ilişkilerden birisi de bireyin kimlik meselesidir. Reklamlarda toplumsal ve bireysel kültür ve kimlik ortak paydasında edebi metinlerle aynı yolda yer alır.

23 Mayıs 2018 tarihinde yayınlanan "BY İLKADIM GRUP TEFAL TÜRKIYYE" başlıklı "Tefal" reklamında ürünün kendi meziyetlerini kendi ağzından aktarması fabl türünün bir örneği olarak toplumun kendi değerleriyle bağdaşır. "Falım" sakız reklamında da mani türünün kullanılması bu türün canlı kalmasını ve sürekli olmasını sağlamıştır.

Küçükerdoğan'a göre reklamlarla oluşturulan ürünlerin farklılığı çevre, değerler, simgeler, markaya bağlı oluşan imgeler tarafından yaratılmakta ve göstergebilim bu yaratımda ön plandadır demiştir. Göstergebilim en genel tanımıyla, dilbilimsel metotları nesnelere uygulayan, her şeyi (oyunlar, jestler, yüz ifadeleri, dini ayinler, edebiyat eserleri, müzik parçaları...) dille tasvir etmeye ve dilsel olmayan bütün olguları da dil metaforuna dönüştürerek açıklamaya çalışan bir bilimdir (Aktaran: Becan, 2012).

4 Eylül 2019 tarihinde yayınlanan "Yataş Bedding | Çeyiz Setleri” başlıklı "Yataş" reklamında verilen nevresim takımlarının modelleri geleneksel, modern, dantelli, nakışlı vs. simgeleriyle sınıf oluşturması ve kimlik ortaya çıkarması ürünün satış amacını sağlamaktadır.

Judith Williamson'a göre reklamlar bize sadece satılan ürünün tanıtılan niteliklerini değil, aynı zamanda o ürünün bizde anlam bulduğunu ve ifade ettiği şeyi satmaya çalıştığını söyler. Reklamlar nesnelerin dilini insanların diline dönüştürebilen ve tersini yapabilen bir yapı oluşturmaktadır. Reklamcılık belli tip tüketiciler ile belli ürünler arasında bağlantı kurmakta ve bu bağı kurduğu ve değişim simgelerini yarattı̆g i için, bunlar verili gibi kullanılabilmektedir (Bourse, 2012).

1 Mayıs 2019 tarihinde yayınlanan "HAMIDIYE SU" başlıklı su reklamında "Hamidiye deyince herkes susar" sloganı ile mecaz anlamda "su", "susamak", "susmak" sözcüklerinden kavramlara ulaşılmış Hamidiye markasının bir otorite olduğu imajı verilmiştir.

Williamson; "Reklamlar, daha çok nesnelerin dilini insanların diline dönüştürebilen ve tersini yapabilen bir yapı oluşturur" demiştir (Akt. Yılmaz, 2004).

Reklam ve reklamcılık yeni bir kültürel açılım oluşturmada; milli kültürün ve milli kimliğin en önemli unsurlarından ve belirleyicilerinden birisi olan "Dil"'in iletişim işlevlerinden yararlandığı gibi, kültürün yap1 taşlarından "Din" müessesesinden ve folklorik göstergelerden (giyim-kuşam, gelenek-görenek vb.) de yararlanmaktadır (Yılmaz, 2004).

5 Haziran 2019 tarihinde yayınlanan "Sana yemedin mi - Sana Reklamı" başlıklı ve 26 Ocak 2014 
tarihinde yayınlanan "Büyüdüm Büyüdüm Pınarla Büyüdüm (Pınar Süt reklamı)" başlıklı "Sana ve Pınar" reklamlarının nesiller boyu kullanılmış olması bu iki ürünün gelenekselleştiği algısını verir. Bu reklamların nesiller arasında köprü kurduklarından bahsedilir. Kültürel boyutta önem taşıyan vurgularla çeşitli sloganlar üreterek ürünün satışını sağlamaktadır. Bir başka yağ markası olan Luna, Sana reklamını atfederek aynı yağın kullanılmasını gelişmeyi engellemiş algısı ile 21 Nisan 2015 tarihinde yayınlanan "Luna Reklamı - Siz Hala Annenizin Margarinini mi Kullanıyorsunuz? (1992)" başlıklı reklamında "Siz hala annenizin margarinini mi kullanıyorsunuz?" slogan ile ürününü tanıtmıştır.

Dil, gündelik hayatta belli bir ideolojiyi destekleyip güçlendiren ve kendiliğinden yeniden üretmeye yardımcı olan unsurlardan biridir. Belli bir amaca uygun anlatım araçlarının oluşturduğu bir imge sistemi olarak dil, öncelikle sözel, daha sonra görsel kodlarla ifade edilmekte ve algılanmaktadır. Diğer görsel kodlar da kültürün oluşturulmasına yardımcı olmaktadır (Mengü, 2006).

10 Eylül 2019 tarihine yayınlanan "Marmarabirlik Reklam Filmi 2019 (HD)" başlıklı zeytin reklamında evli, bekar, yaşlı, genç, çocuk, kadın, erkek tipleri ile hepimizin zeytin vurgusu yapılırken zeytin çeşitlerindeki çeşitlilik ve hedef kitlelerdeki çeşitlilik yansıtılarak verilmiştir.

Kültür ile yakından ilişkili olan bir başka kavram olan tüketim toplumunda kitle iletişim araçlarının mesaj ileticilerinden biri olan reklamlar önemli bir ikna aracı olarak ayrı bir yere sahiptir (Kalan, 2010).

8 Nisan 2014 tarihinde yayınlanan Coca Cola'nın 50. Y11 reklam filminde yerel manzaralar geleneksel yaşamlar üzerinden Türklere has Türkçeye özel sözcüklerle aidiyetlik hissi uyandırarak "Coca Cola" yerine "Koka Kola" yazmanın 50. Y11 hediyesi olarak küçük bir kompozisyon sunulmuştur.

Eğitim, okul, aile ve sosyal çevre olmak üzere üçlü bir saç ayağında gerçekleşir. Günümüzde teknolojinin getirdiği imkanlar aile ve okulun önüne geçmiş, sosyal çevre olarak kabul edeceğimiz medyaya ait herşey, geniş hedef kitleye hitap ederek etkisi altına almıştır. Okul ve ailenin gücü teknolojinin gücünün altında kalmıştır. Sosyal öğrenme kuramı, etkili bir eğitim kuramı olarak okul ve aile eğitiminin gücünü zayıflatmıştır. Geniş hedef kitlelere hitap eden kısa süreli ve sıklığı açısından bilinçli olarak takip edilmese de her zaman etkili bir iletişim aracı olarak reklamlar bireyin yaşamında yer almıştır.

Reklamların kültürel etkisi toplumların ve bireylerin davranış ve tutumlarını etkilemekte, yaşam biçimlerini yeniden şekillendirmektedir.

Bazı reklamlar tamamen tüketim amaçlı olarak sadece duygulara seslenerek kültür ve değerlerin hiçe sayıldığı, ancak cümlenin ögeleri üzerine dikkat edildiğinde ciddi bir sorunun ortaya çıktığı tespit edilebilir. Örneğin; 7 ekim 2016 tarihinde yayınlanan Zen alyans reklamlarında alyans ve alyansı bekleyen genç kız söz konusudur. Alyansı verecek olan asıl özne erkek, sevgili, koca adayı söz konusu bile edilmez. Yani özne önemsizleştirilir nesne öznenin yerine geçer. Evlilikte ise önemli olan asıl özne olan koca adayıdır. Alyans sadece bir nesnedir.

21 Ekim 2019 tarihinde yayınlanan Altınyıldız Classics reklamında nesne Burak'ın önüne geçmiştir. Herkes kazak, smokin, ceket vs. gibi kıyafetleri başarılı bulurken ve kıyafetleri överken tek bir kişinin Burak'1 övmesi onu etkilememiştir. Aynası iştir kişinin lafina bakılarak Burak'ın söylenenlere hiç aldırmaması nesneyi ön plana çıkarmıştır. "İnanırsan başarırsın” sloganı ile verilen üründe özne nesne yer değiştirmesi görülmektedir.

İletişim Sözlüğü'ne göre alg1; "duyularla alımlanan, beyin tarafından işlenen, bellekte depolanan ve fiziksel veya zihinsel bir tepki biçimini üreten enformasyon" (Mutlu, 2004, 17) olarak tanımlanmaktadır (Aktaran: Karatepe, 2008).

Reklamların, halkın tüketiciye dönüşmesini sağlaması için ürünlerin algıda seçiciliğe sahip olması gerekir. Algıda seçicilik için, halkın aşina olduğu bir yaşamla yani kültürle ilişskili olması gerekir. Özenti yoluyla yabancı ögelere yer verilen reklamlarla da sonuca ulaşılabilir. Özellikle krem ve deterjan gibi ürünlerin içinde bulunan kimyasalların sayılması erişilmesi gereken önemli bir faktör algis1 verir. 
Sanal gerçeklikle başlayan serüvende, gerçek görüntülerin yerini sanal bir dünya almaktadır. Artırılmış gerçeklik, verilmek istenen mesajın, görsel, işitsel yöntemlerle 3D olarak görselleştirilmesidir. Sanal ve gerçek dünyanın birleşimiyle oluşan yeni bir dünyadır (Uğur \& Apaydın, 2014).

Teknolojinin imkanları reklamların toplum üzerine etkisini arttırmıştır. Sanal olarak verilen reklam izleyiciyi içine çeker. Buna arttırılmış gerçeklik denir. Uğur ve Apaydın, reklamların sanal olarak etkisini inceledikleri çalışmalarında, sanal bir reklamın ürünü, basılı bir reklamın ürünündan daha fazla etki ettiği sonucuna ulaşmışlardır.

Algılama yönetimi, tüketicinin görüşlerini etkilemek için yapılan faaliyetleri kapsar. Söz konusu tepkilerin arzu edilen yönde gelişmesini sağlama amacını taşır. Esas olan tüketiciyi yönlendirmek, algı aracılığıyla onda tutum ve davranış değişikliği yapmaktır (Aktaran: Demir, 2016).

2 Mayıs 2019 tarihinde yayınlanan "Meryem Uzerli ile 2019 Yaz Reklam Filmi” başlıklı FLO reklamı insan psikolojisinin çeşitli durumlardaki arzu ve heveslerini dile getirerek ürünün tüketilmesini doğal olarak davranışa dönüştüren bir algı yönetimidir.

Eğitim düzeyiyle birlikte, bireyin bilgi ve yeteneği yükselmekte aynı zamanda yeni şeyler öğrenmesi sağlanmaktadır. Öğrenilen yeni şeyler, istek ve gereksinimlerin de değişmesine neden olmaktadır. Bu değişimin istendik davranışa dönüşmesi veya içselleştirilmesi eğitimin görevidir. Eğitim fakülteleri özellikle dil hâkimiyetini kullanabilen Türkçe öğretmenliği bölümü bilinçli tüketiciler yetiştirmekten sorumludur. Tüketicinin ihtiyaç ve gerçekleri ile özendirilen ürünler arasındaki tercihi yapabilecek bilinçli toplum yetiştirmek için eğitimde bununla ilgili konuların müfredata yerleştirilmesi gerekir.

Reklam, çizdiği imajlar yoluyla algıları yönlendirme ve kontrol etme amacıyla kültürel göstergeleri kullanarak tüketicinin duygularını hedef almaktadır (Göksu, 2016).

Türkçe öğretmenliği programında anlama (dinleme ve okuma), anlatma (konuşma ve yazma) yer alan beceriler çalışmalarında teorik bilgilerin yanısıra reklamlarda örnek ve uygulamalar yapılabilir.

Sosyologlar kitlelere bir şeyi yaptırmak için yeryüzünde üç etkili yol bulunduğundan söz ederler: zor kullanma, para ile satın alma, inandırmak. Algılama yönetimi bu 'inandırma" yı kişilerin bilinçlerine ve psikolojilerine seslenerek gerçekleştirir (Türk, 2012).

Güneş'e göre, dilin çeşitli işlevleri vardır. Bunlardan bir tanesi de düzeltme işlevidir. Düzeltme İşlevi: Dil, başkalarının alışkanlıklarını kontrol etmek ve onları düzeltmek amacıyla kullanılır. Daha çok denetim amaçlıdır. Reklamlar da dili kullanarak toplumların yaşamlarını etkiler ve yönlendirir. Bireyin dış etkenlerle yaşamını olumsuz etkilerden koruması için eğitimin bu yaklaşıma dikkat etmesi gerekir.

7 Mart 2017 tarihinde yayınlanan "Filiz Makarna Reklam Filmi 2017 (Kıymalı \& Sebzeli Makarna)" başlıklı Filiz Makarna reklamı nesillerarası farklı alışkanlıkların ürün ile ortadan kalkacağını ifade eden bu reklamda babanın uzlaştırıcı rolü toplumu tüketime heveslendirmektedir.

Sosyal yapıda var olan yaşam örüntüleri bizlere yol gösterici oldukları gibi, bizleri yönlendirip, diğerleriyle bağlayıp, ilişkimizi kolaylaştırırlar. Birbirimizi anlamamızı kolaylaştıran yaşam örüntüleri ayrıca birbirimizi anlayıp nasıl tepki vereceğimiz konusunda da ipucu sağlarlar. Bu örüntüler ayrıca bizim rollerimizi de belirleyen en önemli öğelerdir (Yavuzer \& Şirin, 2013).

Reklamlardaki ürünler toplumdaki sınıf ve normları da oluşturur, rolleri belirler.

Algıda, kişinin algılaması sonucu oluşan gerçeğin, gerçeğin kendisinden daha önemli olduğu ifade edilebilir (Aktaran: Bakan \& Kefe, 2012).

Reklamlar da amaç, satılması gereken ürünün, alınması gereken bir ihtiyaç olduğu gerçeği üzerinden hareket eder. Örneğin; 21 Mayıs 2018 tarihinde yayınlanan Blue Diamond reklamında "Blue Diamond her kadının hakkı" Vurgusu okey durumunda kadın artıdır algısı vermektedir.

Ford Focus'un ayrıcalıklı yaşayanlar sloganı ile ürünü tanıttığı reklamda herkesten farklı olmanın üstünlüğü özenmek algısı ile sunulmuştur.

"Eti Karam" reklamında ise haz sözcügü, üstünde durularak verilmiştir.

Transaksiyonel Analiz, bireyler arasında değişen ilişkiyi ve iletişimi, bireyin diğer bir bireyden 
farklılığını ve diğer bireylerle iletişim kurduğunda nasıl davrandığını açıklamaya çalışan bir yaklaşımdır (Keçeci, 2007). Temel çerçevesi Eric Berne tarafından çizilen Transaksiyonel Analiz, bir kişilik kuramı olarak tanımlanmakta, kişisel değişme ve gelişme için sistematik bir psikoterapi yaklaşımı olduğu ifade edilmektedir (Aktaran: Gültekin \& Voltan-Acar, 2004). Transaksiyonel analizde Eric Berne tarafından tespit edilmiş üç asal rol vardır; Ana-baba rolü (Ebeveyn rolü): Koruyucu ana-baba rolü, eleştirel ana-baba rolü, Çocuk Rolü: Uyarlanmış çocuk, Doğal çocuk, Yetişkin Rolü.

\section{YÖNTEM}

Bu çalışmada Döküman Analiz yöntemi ile tarama yordama tekniği kullanılmıştır. Ayrıca Transaksiyonel analiz çalışmasına dayalı reklamlar üzerinde de durulmuştur. Doküman Analizi: Doküman analizinde temel amaç; araştırması hedeflenen olgu veya olgular hakkında bilgi içeren yazılı materyallerin "incelenme", "bilgi geliştirme" ve "anlam çıkarma" amacıyla analiz edilmesidir (Bowen, 2009; Corbin ve Strauss, 2008; Yıldırım ve Şimşek, 2011).

Transaksiyonel Analiz (TA), bir kişilik kuramı olduğu kadar, bir iletişim kuramı ve bir psikoterapi kuramıdır da. Bu açıdan aslında kişilik oluşumunun ironik bir ifadesi olduğu kadar, çevremizle nasıl iletişim kurduğumuzun ve kişilik ile iletişim sürecinin arızalarını gidermenin yollarını da kendi içinde barındırmaktadır. TA, Ego durumlarından hangisinin olası tepkilerinin uygun olduğunu saptama görevini yüklenir. Bunu yaparken de ebeveyn ve çocuk durumlarından yararlanır (Aktaran: Gültekin \& Voltan-Acar, 2004).

Transaksiyonel analizde Eric Berne tarafından tespit edilmiş üç asal rol vardır;

Ana-baba rolü (Ebeveyn rolü): Koruyucu ana-baba rolü, eleştirel ana-baba rolü

Çocuk Rolü: Uyarlanmış çocuk, Doğal Çocuk

\section{Yetişkin Rolü}

Pek çok reklamda bu rollerin toplumun kültürü ile birlikte işlendiği görülmektedir.

Örneğin; Karaca porselen reklamında en güzel an yaşadığınız an bölümünde koruyucu ebeveyn rolü, 28 Nisan 2015 tarihinde yayınlanan "Korkmaz Kadının Masası Reklamı" başlıklı Korkmaz tencere reklamında Edip Cansever' in "Masada Masaymış Ha" şiirinden uyarlanan sofra göstergesi üzerinde anne koruyucu ebeveyn, ailenin tamamı da çocuk rolündedir.

29 Aralık 2018 tarihinde yayınlanan "Coca Cola 55. Yıl Duygusal Reklamı YENİ "İşte öyle bir şey "” başlıklı Coca Cola reklamında yerel manzaralarla yıllardan beri kullanılan Türk isimlerini ifadesiyle aidiyetlik hissi veren kültürel kimlik işlenmiştir. Reklamda yer alan bütün isimler Yetişkin rolündedir.

Reklamlar, yalnızca ürün satışına yardımcı olan bir faktör olarak algılanamaz. Onu, kimliği biçimlendirici olarak tüketimi sağlamak, cinsel kimliğin ifadesinde ve kimliğin biçimlenmesinde hem kendisinden yararlanılan hem de cinsellik açısından toplumsal kabulleri yansıtan bir kaynak olarak görmek olasıdır (Aktaran: Becan, 2012).

Reklamlarda özellikle kadınlığın özelliği ve farklılığı "güzellik" algısıyla öne çıkarılmakta ve bunu vurgulayacak mit ve mitoslardan da yararlanılmaktadır.

Mitoloji, Türkçe alan yazınının önemli bir konusu olduğu kadar reklamlarda da çok tercih edilen alanlardan biridir. Nemlendirici krem reklamlarında mitsel güzellik adlı çalışmada Şeşen ve Doğan ürünün tanıtımında mitolojinin nasıl kullanıldığını açıklarlar (Şeşen ve Doğan, 2019). 


\section{Reklamların Mit Analizi}

\begin{tabular}{|c|c|c|c|c|}
\hline & & & & \\
\hline & VAAT & PROBLEM & MíT \\
\hline \multirow[t]{2}{*}{ ARKO } & Ürün & $\begin{array}{l}\text { Cildin güzelliğini } \\
\text { koruma }\end{array}$ & $\begin{array}{l}\text { Günlük bakımını } \\
\text { yapamama }\end{array}$ & $\begin{array}{l}\text { Mücevherden daha } \\
\text { değerli }\end{array}$ \\
\hline & Kullanıcı & Güzellik & Bakımsızlık & Güzel ve değerli kadın \\
\hline \multirow[t]{2}{*}{ BEPANTHOL } & Ürün & Cildi koruma & $\begin{array}{l}\text { Vitaminsiz kalmış, kuru } \\
\text { ve hassas cilt }\end{array}$ & $\begin{array}{l}\text { Güzelliğin arkasındaki } \\
\text { gizli güç }\end{array}$ \\
\hline & Kullanıcı & Güzellik & $\begin{array}{l}\text { İş ve ev arasında cilt } \\
\text { bakımına zaman } \\
\text { ayıramama }\end{array}$ & $\begin{array}{l}\text { Her şeye yetişen bakımlı } \\
\text { ve güzel kadın }\end{array}$ \\
\hline \multirow[t]{2}{*}{ GARNIER } & Ürün & Cildin hak ettiği bakım & $\begin{array}{l}\text { Nemlendiricileri } \\
\text { kullanmak zorunda kalma }\end{array}$ & $\begin{array}{l}\text { Daha uzun süreli ve etkili } \\
\text { canlılık }\end{array}$ \\
\hline & Kullanıc1 & Güzellik & $\begin{array}{l}\text { Kendisine hak ettiği } \\
\text { bakımı verememe }\end{array}$ & $\begin{array}{l}\text { Bakımlı, yeniliğe açık } \\
\text { kadın }\end{array}$ \\
\hline \multirow[t]{2}{*}{ LOREAL } & Ürün & Yaşa özel nemlendirme & Gençliği koruyamama & $\begin{array}{l}\text { Genç bir görünüm, } \\
\text { gençlik }\end{array}$ \\
\hline & Kullanıc1 & Güzellik & Yaşlanma & Her yaşta güzel kadın \\
\hline \multirow[t]{2}{*}{ NIVEA } & Ürün & $\begin{array}{l}\text { Cildi canlandırıp } \\
\text { yenileme }\end{array}$ & $\begin{array}{l}\text { Cildin canlılı̆̆ını } \\
\text { kaybetmesi }\end{array}$ & $\begin{array}{l}\text { Derinlemesine } \\
\text { gençleştirme }\end{array}$ \\
\hline & Kullanıcı & Güzellik & $\begin{array}{l}\text { Şehir hayatında doğallığ1 } \\
\text { ve canlılığ kaybetme }\end{array}$ & Gençlik ve güzellik \\
\hline
\end{tabular}

Kaynak: Şeşen \& Doğan (2019, s. 111).

Bu tabloya bakıldığında sağlık, güzellik gibi alanların ürünü olan yaş ve cinsiyet ayırmaksızın her kitleye hitap eden kremlerin iletideki mesajları görsel ve metin okumayla birlikte mitolojik ögelerden faydalanılarak yapıldığı görülmektedir. Etkili iletişim için de örnek olabilecek bu tarama mitolojinin ifade gücündeki önemini ortaya koymaktadır.

Eğitimde önemli bir konu olan yansıtıcı düşünce ilk defa 1910 yılında Jhon Dewey tarafından How We Thınk adlı çalışmasında ele alınmıştır. Sorgulamayı amaçlayan bu çalışmanın önemli basamaklarından birisi "yerine koyabilmek" tir. Bunun bir örneği olarak 22 Ekim 2019 tarihinde yayınlanan "Migros İstanbul Kart" başlıklı migros reklamında yapılan alışveriş puanlarının akbil yerine kullanılması örneği verilebilir.

Aşağıda incelemesi yapılacak olan Reklamda toplumun kadın ve erkeğe verdiği yükümlülükler ilişkideki değerleri ortaya koymaktadır.

Avea Reklamlarındaki Fasulye tiplemesiyle, "Hiçbir işe yaramayan fakat kendini beğenmiş" anlamında "Fasulye gibi kendini nimetten sayan" deyiminin örneklemesiyle oynayan karakter, Transaksiyonel Analizin Doğal Çocuk rolünü temsil eder.

Avea bu kategorideki reklamlarla, günlük hayatımızda çok çeşitli olaylar karşısında, problemleri çözemeyen "mağdur" rolünde "fasulye", problemleri çözen, "akıllı, kararl1, yeniliklerden haberi olan" rolünde zaman zaman kız arkadaşı, zaman zaman da "optik" tiplemesiyle erkek arkadaşı oynatmıştır.

Mecaz sanatının hâkim olduğu reklamlar, "Fasulye" renk değiştiriyor bölümünde "T A çocuk" rolünün s1k sık düşebileceği gaflarla üzülme veya utanma gibi duyguları, sahilde bronzlaşmak eylemiyle ifade edilmiştir. Tatilde bronzlaşamayan "Fasulye" yi Optik ürünün yeni bir kampanyasıyla "mosmor" etmiştir. Kampanyayı duyan Fasulye şaşkın ve üzgün mimikleriyle güneşlenmekten daha fazla yanmıştır.

"Fasulye" nin aşk hayatı hiçbir zaman yetişkininki gibi değildir. Sürekli parasızlık çeken Fasulye kız arkadaşına, her delikanlı gibi çiçek almak ister fakat sevgilisi, avealı olmadığı için iki yakası bir araya gelmeyen "fakir ama gururlu "erkeğine firsat vermeden çiçekçiye parayı öder. Bir yandan şaşkınlık bir yandan itiraz mimikleriyle kekeleyen "Fasulye"yi sevgilisi bir koruyucu anne şefkatiyle teselli eder. Evlilik programı ve Banu Avea bölümlerinde "Fasulye" doğal çocuk ve madur masalı vardır. İndirimleri göremiyorum bölümünde sevgilisinin indirim neşesine anlam veremeyen Fasulye önce avealı olmadığı için acıyarak indirim günlüğünü verirken, bir çocuk gibi konuşmasını taklit eder, daha 
sonra durumun vahametini eski Türk filmlerinin klasiği olan kör delikanlı esprisiyle acınaklı mimikleri kullanır.

"Fasulye" nin kafası doldu bölümünde "Fasulye" pek çok bölümde olduğu gibi pür neşe sanal alemde optikle gezinirken crazy-girl 89' u görür. Liseli bir aşı gibi çarpılır. Fakat hızla kıza doğru koşarken günlük hayatımızdaki "güvenlik", sanal alemin kota koruyucusu olarak karşımıza dikilir. Eleştirel ama baba rolüyle limitsizlikten kıza kavuşmasını engeller. Fasulye doğal çocuk rolüyle engeli aşmaya çalışır ama dertli dertli oflama çeker. Tabi mimikler de esefle iç geçiren üzgün âşık mimikleridir.

Kısmetin Geldi adıyla evlilik programına katılan "Fasulye" her genç kızın rüyası olan sigortalı iş ve tapulu evi olmasına rağmen aday ve annesi tarafından Faturalı Avea hattı olmadığı için reddedilir. Gelin adayı kız Optik' i tercih edince hem kızgın hem de kaderine küskün mimiklerle program biter.

Halı sahada maç yapan mahalleli, sahanın şerefi için para toplar. Parayı toplayan delikanlı Fasulyeye gelince sırayı atlar. Parayı ödemeye hazırlanan Fasulye kendisi "es" geçilince çok şaşırır ve saf saf hesap sorar. Parayı toplayan delikanlı Fasulyenin omzunu pışpışlar ve ona çok yüklendiklerini söyler, Fasulye durumu çaresiz üzgün çocuk mimikleriyle kabul eder, Ramazan'da para toplamaya gelen davulcu da Fasulyeyi hemen tanır ve para almak istemez, davulun gürültüsünden korkuyla kapıyı açan Fasulye hazırladığı bahşişi uzatırken, arkasını dönüp giden davulcunun ardından kalakalır. Yeşilçam klasiklerinde olduğu gibi, kapıda acz içinde gitme diye yalvarsa da nafiledir. Üzgün çocuk mimikleriyle adeta terk edilmiş sevgili perişanlığı içinde "vur davulcu sonda vur" acısını ifade eden son sözler ağzından dökülür.

KPSS üniversiteli olmayla kamulu olma benzetmesi bölümünde Fasulye her bölümde olduğu gibi neşeli, heyecanlı, keyifli sınava başlar. Birinci doru da doğru cevap Avea olması gerekirken Fasulye karar veremez. Doğal çocuk rolüyle iki sıra önde oturan Optik' ten hapşırarak kopya almak ister. Doğal olarak da yakalanır.

Avea'nın ikinci bölümünde ise TA, bireyin mesleği ve fiziği ön plana çıkarılarak çalışılmıştır. Çaycı, güvenlikçi, temizlikçi gibi vasıfsız meslekte ama oldukça cüsseli, pratik ve girişken elemanlar, toplumun elit tabakasını oluşturan minyon tipli mühendisleri, çocuk rolüne alarak ana baba rolüne çıkmışlardır.

Yorgunluktan bitap düşmüş çelimsiz bir mühendisi koltuğunun altına alan güvenlikçi, ben huzur ortamını sağlamasam bu mühendis hiçbir şey üretemezdi, çay kahve akışını sağlayarak oralet Ahmet lakabıyla mühendisleri canlı tutan çaycı ve saçlarını süpürge ederek hijyen sağlayan temizlikçi Cemile Tezel teknik kadronun başarısını biz olmasaydık başarı olmazdı diyerek üstlenirler.

Sosyal, özel, mesleki hayatlarımızda ki ilişkilerimizde her an geçerli olan TA, avea'nın bu bölümünde "komşu komşunun külüne muhtaçtır" atasözüyle ötekileşmeyi engeller. Bu gruptaki reklamlar, adeta sosyolojik bir ekolojiyi formüle ederek, herkesin herkesi kabul etmesini ve herkesin herkesi saymak erdemini sahneler.

\section{SONUÇ VE ÖNERILER}

Türkçe öğretmenliği alan yazınındaki her bilgi, her konu, günlük yaşamında kendini var eden dili sayesinde bireyin ve toplumun en temel gereksinimidir. Reklamlarda gelip geçici bir ürünün tüketilmesi amacına ulaşılabilmesi için hitap ettiği toplumun dilinin bütün özelliklerinden faydalanmak zorundadır. Türkçe dil bilgisi dersinin önemli bir konusu olan yansıma seslerinin bir örneği 18 Şubat 2019 tarihinde yayınlanan "Eti Crax Reklamı-Crax'la Sen! Nasıl Eğlenmek İstersen" başlıklı "eti crax" reklamında kullanılmıştır. Krakerin 1sırırken çıkardığ 1 ses ürünün adı olmuştur. Reklam sloganı ise "sen" sözcüğü ile varoluşculuğun öne çıkmasını eğlenmek isterken de tercihlerinde özgürlüğü kastederek ürünü özelleştirmişlerdir.

Araştırıcılar, yazarlar arasında televizyonun çocuk bakıcılarının, anne ve babanın yerini aldığını söyleyenler pek çoktur. Hatta bir araştırıcı cesaretle daha ileri giderek, kitle haberleşme araçlarımn çocukların yeni aileleri olduğunu söylemektedir. (Aktaran: Tokgöz, 1979). Bu kadar etkili olan teknolojik iletişim araçlarını eğitimde ihmal edilmemesi önemsenmesi gerekir. Reklamların bu etkisi çerçevesinde çocuklara okulda verilen eğitimden önce sezdirilerek Türkçe öğretimindeki pek çok 
konunun ön hazırlı̆ğ verilmiş olur. Bu da yapılandırmacılık açısından önemlidir.

Eğitimin önemli bir malzemesi olan medya, reklamlar yoluyla geniş hedef kitlelerine ulaşabilmektedir. Reklamlar önemli bir iletişim aracı olarak toplumun sosyal hafizasını etkilemekte kollektif şuurunu oluşturmaktadır. Eğitimde amaçlanan kültürel hedeflere ulaşmada kollektif şuurun ortak paydası reklamlar yoluyla verilebilmektedir.

Reklamların olumlu ve olumsuz taraflarını görebilmek değer yargıları ve kültürel açıdan önemini tespit edebilmek eleştirel düşünmeye bağlıdır. Eleştirel düşünme becerisi kazanmış bireylerin yanlışı ve doğruyu ayırt edebilme özelliği reklamlar içinde geçerli olacaktır. Eleştirel düşünme becerisine sahip bireylerin tüketim toplumu olmaktan çok ihtiyaçlarına yönelik ekonomilerini ayarlamaları söz konusu olacaktır. Eğitimcilerin eleştirel bakışı teorik bilgilerle vermek yerine reklam ürünlerini ele alarak etkinlik ve uygulama yapmaları sosyal öğrenme açısından kolaylık sağlar.

Reklamların gösterge, imge, simge ve kodlama gibi unsurlarla ifade edilmesi edebi metin yazarlığıyla yakın ilişkilidir. Bir edebi metni anlamanın ve algılamanın okuma becerisiyle bir reklamı okuma becerisi aynıdır. Reklamların somut anlamda kullandıkları ifadelerin mecaz anlam, yan anlam, soyut anlam gibi anlam bilime dayalı ifadeleri bireyin yönlendirilmek istedikleri amacını ortaya koymakta ve bu amaca bilinçli bir şekilde yaklaşılması sağlanmalıdır.

Reklamlar somut anlamın dışında unsurlarla ifade edildiği için bireyin soyut düşünme becerilerine sahip olması gerekir. Kısaca bireylerin kitle iletişim araçlarını, kişisel gereksinimlerini doyuma ulaştırmak için kullandıklarını savunan kurama göre, izleyiciler proaktif olarak kendi gereksinimlerini doyuran iletişim sunularını seçerler (Bölükoğlu, 2003). Bireyin kişisel ihtiyaçlarına göre tercihlerini kullanması eğitimde doğru yönlendirme için dikkat edilmesi gereken en önemli konudur. Proje tabanlı öğrenme, işbirlikçi öğrenme gibi grup halinde yapılacak çalışmalarda aynen reklamlarda dikkat edilen bu ihtiyaçların iyi belirlenmesi ve bunlara göre kurulan ekiplerin önemini öğrenciye aktarmak gerekir.

Konuşmanın gerçekleşebilmesi için beynin iki yarıküresi de eş güdümlü çalışır. Yani sol yarım kürede anlamlı tümceler oluşturulurken, sağ yarım kürede bu tümcelere vurgu, ezgi, ton katar (Aktaran: Mert, 2014). Reklamlar, beynin iki yarımküresine de hitap ettiği için iyi bir metin diliyle yazılmışsa bireyde kalıcı etki gösterir. Aynı tarzda eğitimde de beynin iki yarım küresine hitap ederek reklamdaki gibi etkiyi sağlamak mümkündür. Görsel sunumlar, eğitimde ağırlıklı biçimde kullanılmalıdır.

Reklamlarda iletilen mesajlar, hedef kitlenin belleğinde ürüne yönelik olumlu düşünceler yaratmak, potansiyel alıcıları ürünün alıcısı haline getirmek, mevcut pazarı sadık alıcı olarak elde tutmak ve nihayet malın benzeri diğer mallardan farklı olduğu imajını tüketici belleğine kazımak amacına yöneliktir (Lembet, 2012). Reklamlardaki hedef kitlelere hitap eden mesajlar sloganlar şeklinde ifade edilirken derslerde öğretmenlerin bilginin önemini vurgulayan ifadelerde de söylemlere dikkat etmelidir. Eğitimde söylem analizinin önemi dikkate alınmaya başlanmış bununla ilgili çalışmalar artmıştır. Söylem analistlerinin bulgularına göre hem diyalojik hem de monolojik hamleler kaliteli bir sınıf söylemi için olmazsa olmazdır (Soysal, 2019).

Geleneksel eğitimdeki sadece bilginin aktarılmasının eğitimdeki sorunların çözülmeye başlanmış yerine daha modern, bilginin kalıcılığını sağlayan yeni metot ve teknikler geliştirilmiştir. Bu metot ve tekniklerin yanısıra Solo ve Bloom'un üzerinde durduğu özellikle analiz, sentez ve kavrama basamaklarında bilginin vurgulanması gereken yerlerin söylem analizleriyle işlenmesi eğitimde başarıyı sağlar.

Feuerstein; özellikle eleştirel düşünmenin ve reflektif düşünmenin geliştirilmesiyle bağlantılı temel alanlardan biri olan medya okuryazarlığı. Medyanın ve medya mesajlarının içeriği üzerine çalışarak ve eleştirel karşılıklar vererek üst-bilişsel, reflektif stratejiler geliştirmeyi amaçlamaktadır (Aktaran: Görmez, 2015). Medya'nın okul kadar büyük etkisi olduğu bilinirken media okuryazarlığı sadece iletişim fakültelerinde eğitimi verilmemeli eğitim fakültelerinde de media okuryazarlı̆̆ eğitimine yer verilmeli ve öğretmen adayları bu eğitimle yetişmelidir.

Reklamlara genel olarak bakıldığında derin anlamda ortaya çıkan kelimeler şunlardır; güç, haz, mutlu ol ve sen önemlisin. $\mathrm{Bu}$ iletiler toplumun günlük yaşama biçimini oluşturduğu gibi ürününde tüketicisini arttırmaktadır. Alg1 yönetimi ile verilen bu iletiler eğitimin önüne geçmektedir. MEB'in 
genel ve özel amaçlarında ele alınan kişilik gelişiminde ve etik değerlerde beklentileri karşılamak ve iyi bireyler yetiştirmek açısından tüketim amaçlı bireyi yanlış yönlendiren kavramlardan uzak tutmak için bu sektörün takip edilmesi gerekir. Okul ve aile kadar önemli olan sosyal ortamdaki yanlış ögretiler eğitimciler tarafından takip edilerek alternatif eğitim geliştirmelidirler.

Popüler kültürün öncülüğünü yapan reklamlar, Maslow hiyerarşisinde bir basamaktan öteye bir anlam vermeyen felsefesi olmayan bilinçsiz tüketicilere yöneliktir. Eğitim bunun önüne geçecek bilinçli tüketiciler yetiştirmek zorundadır.

Türkçe eğitiminin pek çok konusunu işlevsel olarak kullanan reklam sektörü, öğrenciye ön hazırlık olarak sezdirme yöntemi ile dil ve kültürünü öğretmiş olur.

Bilgilendirme / Acknowledgement: 11. Uluslararası Çin'den Adriyatik'e Sosyal Bilimler Kongresi, Bursa, 8-10 Kasım 2019'da sunulmuştur.

\section{KAYNAKÇA}

Akkoyun, F. (2016). Saygı kavramına transaksiyonel analiz (TA) açısından bakış. Türk Psikolojik Danışma ve Rehberlik Dergisi, 1(4), 16-22.

Akkoyun, F. (1995). Transaksiyonel analiz ve yetişkin olmak. Ankara Üniversitesi Eğitim Bilimleri Dergisi, 28(1), 2-11.

Aktuğlu, I. K. (2006). Tüketicinin bilgilendirilmesi sürecinde reklam etiği. Küresel İletişim Dergisi, (2), 1-20.

Aktuğlu, I. ve Eğinli, A. (2010). Küresel reklâm stratejilerinin belirlenmesinde kültürel farkl1lıkların önemi. Selçuk Üniversitesi İletişim Fakültesi Akademik Dergisi, 6(3), 167-183.

Altay, A. A. (2000). Reklam çevirisi. Hacettepe Üniversitesi Edebiyat Fakültesi Dergisi, 17(1), 33-41.

Arslan, E. (2014). Türkiye'de reklam sloganlarının gündelik dil pratikleri üzerindeki etkisinin değerlendirilmesi: Ege üniversitesi öğrencilerine yönelik bir araştırma. Marmara İletişim Dergisi, (21), 57-72.

Aslan, A. ve Ünlü, D. G. (2016). Instagram fenomenleri ve reklam ilişkisi: Instagram fenomenlerinin gözünden bir değerlendirme. Maltepe Üniversitesi İletişim Fakültesi Dergisi, 3(2), 41-65.

Aslan Kütük, S. (2012). Reklâmlarda beden kullanımının cinsiyet ve kimlik üzerinden araştırılması. Yayımlanmamış yüksek lisans tezi, Haliç Üniversitesi Sosyal Bilimler Enstitüsü Grafik Tasarım Ana Sanat Dalı Grafik Tasarım Programı, İstanbul.

Aslan, V. (2012). Reklam iletilerinde tüketici davranışlarını belirleyen psikolojik etmenler: Üniversitelerin gazete reklamları uygulama örneği. The Turkish Online Journal of Design Art and Communication, 3(3), 9-17.

Babaoğul, M. ve Buğday, E. B. (2012). Gösteriş tüketimine karşı gönüllü sadelik. Tüketici Yazıları (III), 76-87.

Bağc1 Ayranc1, B. (2017). Sezdirme yöntemi ile dil bilgisi öğretimi üzerine Türkçe öğretmenlerinin görüşlerinin incelenmesi. International Journal of Languages' Education and Teaching, 5(4), 145-164.

Bakan, İ. ve Kefe, İ. (2012). Kurumsal açıdan alg1 ve algı yönetimi. Kahramanmaraş Sütçü İmam Üniversitesi İktisadi ve İdari Bilimler Fakültesi Dergisi, 2(1), 19-34.

Bakir, U. ve Çelik, M. (2013). Tüketim toplumuna eleştirel bir yaklaşım: kültür bozumu ve yıkıcı reklamlar. Selçuk Üniversitesi İletişim Fakültesi Akademik Dergisi, 7(4), 46-63. 
Batı, U. (2006). Reklam dilinin biçimbilimsel nitelikleri üzerine bir içerik analizi. Galatasaray Üniversitesi İletişim Dergisi, (4), 149-166.

Bayçu, S. U. ve Uluyağcı, C. (2005). Görsel ve sözel göstergeler açısından bir reklam çözümlemesi: Beymen örneği. Gazi Üniversitesi İletişim Fakültesi Dergisi, (21), 77-99.

Becan, C. (2012). Yeni (duyuşsal) reklam iletileri bağlamında "göstergeleri" okumak: göstergebilimsel yöntemden yararlanarak bir reklam iletisi çözümlemesi. Yalova Üniversitesi Sosyal Bilimler Dergisi, 2(4), 36-52.

Benjamin, L. T. ve Baker, D. B. (2004). Industrial-organizational psychology: the new psychology and the business of advertising. From séance to science: A history of the profession of psychology in America, 118-121.

Bourse, H. Y. (2012). Reklam ve ideoloji: subliminal reklam ve örnek incelemeler. Galatasaray Üniversitesi İletişim Fakültesi, Vize Ödevi, 1-20.

Bölükoğlu, H. İ. (2003). Görsel kirlilik ve sanat eğitimi. Atatürk Üniversitesi Kazım Karabekir Eğitim Fakültesi Dergisi, (8), 101-112.

Çetin, B. N. (2014). Yeniden anlamlandırma aracı olarak reklam. Electronic Turkish Studies, 9(5), 559-573.

Çınar, B. ve Karahan, L. (2009). Reklam dilinde kullanılan edebî sanatlar. Electronic Turkish Studies, 4(8), 891-916.

Demir, N. K. (2005). Kimliklere ayna tutan reklam fotoğrafları. Manas Üniversitesi Sosyal Bilimler Dergisi, (14), 237-251.

Demir, Z. (2016). Tüketici davranışlarında algl yönetiminin rolü: Ünlü algısının kadın tüketici davranışlarına etkisi üzerine bir araşstırma. Yayımlanmamış yüksek lisans tezi, Kadir Has Üniversitesi Sosyal Bilimler Enstitüsü, İstanbul.

Elden, M. (2003). Hedef kitle davranışlarını etkileyen psikolojik bir faktör olarak öğrenme: öğrenme ve reklam ilişkisi. Gazi Üniversitesi İletişim Fakültesi Dergisi, 18(1), 1-29.

Fennis, B. M. ve Stroebe, W. (2015). The psychology of advertising. $2^{\text {nd }}$ Edition. London: Psychology Press.

Friestad, M. ve Wright, P. (1995). Persuasion knowledge: Lay people's and researchers' beliefs about the psychology of advertising. Journal of consumer research, 22(1), 62-74.

Goodwin, C. J. (1999). Applying the new psychology: Applying psychology to business. A History of Modern Psychology, New York: John Wiley \& Sons, Inc. pp. 242.

Goodwin, C. J. (1999). The origins of behaviorism: A new life in advertising. A History of Modern Psychology, New York: John Wiley \& Sons, Inc. pp.315-317.

Göçer, A. (2015). Temel dil becerilerinin geliştirilmesinde dil bilgisi öğrenme alanının yeri, işlevi ve öğretimi: bütünlük ilkesi ve tümevarım yöntemi ekseninde tematik bir yaklaşım. Eğitim ve Öğretim Araştırmaları Dergisi, 4(1), 233-242.

Göksu, O. (2016). Algı yönetimi ve reklam: Reklamı anlamlandırmak. İstanbul. Derin Yayınları.

Görmez, E. (2015). Etkili medya okuryazarlığı eğitimi ve uygulamalarından örnekler. Bitlis Eren Üniversitesi Sosyal Bilimler Enstitüsü Dergisi, 4(1), 93-111.

Gültekin, F. ve Acar, N. V. (2004). Transaksiyonel analizin Türk kültürüne uygulanabilirliğii: Kültür açısından eleştirel bakış. Ĕgitim ve Bilim, 29(133), 28-38.

Güneş, F. (2013). Dil bilgisi öğretiminde yeni yaklaşımlar. Journal of Language and Literature, 2(7), 71-92.

Güneş, F. (2013). Yapılandırıcı yaklaşımla dil bilgisi öğretimi. Journal of Theory \& Practice in Education (JTPE), 9(3), 71-187. 
Güz, N. ve Küçükerdoğan, R. (2005). Göstergeküreler, reklam ve "öteki" kavramı. Journal of istanbul Kültür University, (1), 65-73.

Haşıloğlu, M. F. (2008). Basın reklamlarında göstergelerin kullanımı. Yayımlanmamış yüksek lisans tezi, Atatürk Üniversitesi Sosyal Bilimler Enstitüsü Resim Anasanat Dalı, Erzurum.

İnce, I. (1993). Reklam diline dilbilimsel bir bakış. Hacettepe Üniversitesi Edebiyat Fakültesi Dergisi, 10(1), 231-245.

Kalan, Ö. G. (2010). Reklamda çocuğun toplumsal cinsiyet teorisi bağlamında konumlandırılışı: 'kinder' reklam filmleri üzerine bir inceleme. İstanbul Üniversitesi İletişim Fakültesi Dergisi/ Istanbul University Faculty of Communication Journal, 1(38), 75-89.

Karatepe, S. (2008). İtibar yönetimi: Halkla ilişkilerde güven yaratma. Elektronik Sosyal Bilimler Dergisi, 7(23), 77-97.

Keçeci, A. (2007). Hemşirelik eğitiminde iletişime yeni bir yaklaşım: Transaksiyonel analiz. Ulusrarası Insan Bilimleri Dergisi, 4(2), 1-12.

Kırtay, O. (2012). Reklam iletilerinde mizah kullanımı: Öğeler, teknikler ve uygulama örnekleri. Yayımlanmamış yüksek lisans tezi,, İstanbul Kültür Üniversitesi Sosyal Bilimler Enstitüsü, İstanbul.

Lembet, Z. (2012). Kültür, dil, tüketim ve reklam ilişkisi. Tüketici Yazıları III. TÜPADEM, TÜKÇEV, 44-65.

Maden, S. (2012). Ekran okuma türleri ve Türkçe öğretmeni adaylarının ekran okumaya yönelik görüşleri. Dil ve Edebiyat Eğitimi Dergisi, 1(3), 1.

Mengü, M. M. (2006). Reklam sloganları ve tüketici zihni. İstanbul Üniversitesi İletişim Fakültesi Dergisi, (25), 109-121.

Mert, E. L. (2014). Türkçenin eğitimi ve öğretiminde dört temel dil becerisinin geliştirilmesi sürecinde kullanılabilecek etkinlik örnekleri. Ana Dili Ë̆itimi Dergisi, 2(1), 23-48.

Okan, Z. A. (1998). Dil ve cinsiyet: reklam dili çözümlemesi. Çukurova Üniversitesi Sosyal Bilimler Enstitüsü Dergisi, 5(5), 187-198.

Oregan, D. (2019). How to use psychology in advertising to make people buy. 1 Aralık 2019 tarihinde https://coschedule.com/blog/author/denille-oregan/ adresinden erişildi.

Özarslan, E. (2013). Basın dili üzerine bazı dikkatler. İletişim Kuram ve Araştırma Dergisi, (37), 251267.

Özerk, H. Ada, S. ve Özerk, H. (2018) Öğretmenlerin ve okul yöneticilerinin birbirlerinde algıladıkları ve bekledikleri ego durumlarının ilişkisi. Elektronik Sosyal Bilimler Dergisi 17(66), 779-800.

Özkan, H. H. (2006). Popüler kültür ve eğitim. Kastamonu Eğitim Dergisi, 14(1), 29-38

Snyder, M., ve DeBono, K. G. (1985). Appeals to image and claims about quality: Understanding the psychology of advertising. Journal of personality and Social Psychology, 49(3), 586.

Soysal, Y. (2019). Fen öğretiminde öğretmenin söylemsel hamlelerinin öğrenenlerin akıl yürütme kalitelerine etkisi: Söylem analizi yaklaşımı. Ĕ̈itimde Nitel Araştırmalar Dergisi, 7(3), 9941032.

Şen, M. (2008). Modern zamanların reklam dilselliğinde küresel ve yerel özellikler: Eleştirel Dilbilimsel Bir Bakış. Journal of International Social Research, 1(4), 523-542.

Taşkıran, N. O. ve Bolat, N. (2013). Reklam ve algı ilişkisi: reklam metinlerinin alımlanmasında duyu organlarının işlevleri hakkında bir inceleme. Beykent Üniversitesi Sosyal Bilimler Dergisi, $6(1), 49-70$.

Tokgöz, O. (1979). Televizyon reklamları ve çocuklar. Ankara Üniversitesi SBF Dergisi, 34(1), 93110. 
Turgut, E., Akyol, A. ve Giray, S. (2O16). Sosyal medya reklamlarında tüketici algılamaları ile satın alma niyeti ve ağızdan ağıza iletişim arasındaki ilişki. Journal of Life Economics, 3(2), 55 74.

Türk, M. S. (2012). İletişimde algı yönetiminin önemi. Gazi Üniversitesi IIletişsim Fakültesi, 1-9.

Uğur, İ. ve Apaydın, Ş. (2014). Artırılmış gerçeklik uygulamalarının reklam beğeni düzeyindeki rolü. Humanities Sciences, 9(4), 145-156.

Şeşen E ve Doğan Ş. (2019). Nemlendirici krem reklamlarında mitsel güzellik. s.106-113. Uluslararası 29 Ekim Bilimsel Araştırmalar Sosyal ve Beşeri Bilimler Tam Metin Bildiriler. 26-29 Ekim 2019, İzmir.

Yavuz, Ş. (2006). Reklam ve popüler kültür. İstanbul Üniversitesi İletişim Fakültesi Dergisi, (27), $149-161$.

Yavuzer, H. ve Şirin, M. R. (2013). Sosyal kontrol çocuk ve internet (Nurgün Oktik). s.297-309. I. Türkiye Çocuk ve Medya Kongresi Bildiriler Kitabı, Çocuk Vakfi Yayınları, İstanbul.

Yılmaz, E. (2004). Medyatik dil alanları: Reklamcılık dili üzerine metin dil bilimsel bir inceleme. Türk Dili, 634, 383-400.

Yurdakul, N. B. (2003). İşletme yönetiminde iki stratejik görev: İmaj-marka yönetimi ve müşteri ilişkileri yönetimi. Manas Üniversitesi Sosyal Bilimleri Dergisi, 8(1), 205-211. 